Jurnal Kesehatan Masyarakat \& Gizi, e-ISSN: 2655-0849

Vol. 3 No.2 Edisi November 2020 - April 2021

https://ejournal.medistra.ac.id/index.php/JKG

Received: 22 April 2021 :: Accepted: 30 April 2021 :: Published: 30 April 2021

\title{
PENGARUH PROMOSI KESELAMATAN DAN KESEHATAN KERJA (K3) TERHADAP PENGGUNAAN ALAT PELINDUNG DIRI DAN PERILAKUTIDAK AMAN DI PT.CINTA RAJA SERDANG BEDAGAI
}

Luci Riani Br Ginting ${ }^{1}$, Delita Br Panjaitan², dan Febriyanta ${ }^{3}$ Progaran Studi Kesehatan Masyarakat Fakultas Kesehatan Masyarakat Institut Kesehatan Medistra Lubuk Pakam

Jl. Sudirman No.38 Lubuk Pakam Kec. Lubuk Pakam Kab. Deli Serdang, Sumatera Utara

Email: luci.riani@gmail.com

DOI $10.35451 / \mathrm{jkg} . \mathrm{v} 3 \mathrm{i} 2.661$

\begin{abstract}
The use of Personal Protective Equipment (PPE) many factors that cause workers are not compliant to use PPE, even though the company has provided PPE and implementing regulations that require workers to use PPE. Companies must also create workforce compliance to use PPE. The most basic stage to foster workforce awareness so that compliance with PPE is by establishing a safety culture using PPE. This type of research is experimental. The study design was a quasy experiment with a time series design approach. The study design was a pre-experimental (One group pre and post test design) that is a study that used a group of subjects, measurements were carried out before and after treatment. This study uses a non-probability sampling method, which is a sampling method where only certain individuals or objects in a population are selected as samples. The sampling technique in this study is total sampling, which is a sampling technique where the number of samples is equal to the population. Based on the results of statistical tests using paired sample t-test with a confidence level of $95 \%(a=0.05)$ obtained $p$ value $=0,000 \leq 0.05$, meaning that there is an effect of $K 3$ promotion on the use of personal protective equipment at PT. Cinta Raja in 2020. It is hoped that PT. Cinta Raja should pay attention to its employees in using personal protective equipment to minimize work accidents.
\end{abstract}

Keywords: K3 promote, APD use, Unsafe behaviour 
Jurnal Kesehatan Masyarakat \& Gizi, e-ISSN: 2655-0849

Vol. 3 No. 2 Edisi November 2020 - April 2021

https://ejournal.medistra.ac.id/index.php/JKG

Received: 22 April 2021 :: Accepted: 30 April 2021 :: Published: 30 April 2021

\section{PEndahuluan}

Alat-alat telah digunakan untuk membantu pekerjaan manusia pada zamanserba modern ini, dan dapat memudahkan pekerjaan manusia, salah satunya mesin yang sudah digunakan. Bantuan menggunakan mesin yang dapat meningkatkan produktivitas, disamping kualitas yang semakin baik dan standar, dengan hadirnya alat modren pada zaman sekarang, pada perusahaan besar maupun perusahaan keciltidak lagi membutuhkan tenaga kerja yang banyak. Kehadiran alat modren seperti mesin mempunyai keuntungan yang cukup besar bagi penggunanya, namun dapat juga membuat kerugian karena mesin dampaknya seperti dapat terjadi rusak, meledak atau terbakar.

Dari data International Labour Organization (ILO) tahun 2017, di dapatkan satu pekerja di Dunia dapat meninggal setiap 15 detik d karenakanterjadinya kecelakaan kerja dan jumlah 160 orang pekerja mengalami kondisi sakit akibat kerja, sedangkan pada tahun sebelumnya tercatat angka kematian disebabkan oleh kecelakaan dan terjadinya penyakit akibat kerja (PAK) pada kasus setiap tahun sejumlah 2 juta kasus.Dari data statistik disebutkan bahwa kecelakaan kerja pada Jamsostek di data hingga akhir tahun 2016 sejumlah 103.074 kasus kecelakaan kerja, dengan rerata 282 kasus kecelakaan kerja terjadi setiap harinya. Sedangkan pada tahun 2017 kasus kecelakaan kerja mencapai 103.285 yang berarti terjadi kenaikan sejumlah $1,76 \%$, kemudian pada tahun 2018 angka kecelakaan kerja mencapai 8.900 kasus di hitung dari bulan Januari sampai April 2018. Heinrich mengatakan bahwa kecelakaan kerja yang timbul secara umum dapat disebabkan oleh 2 hal penting yaitu adanya tindakan tidak aman (unsafe action) serta kondisi tidak aman (unsafe conditions). Menurut Heinrich juga dapat memperkirakan bahwa kecelakaan kerja yang terjadi $85 \%$ merupakan kontribusi dari perilaku kerja yang tidak aman. Berdasarkan masalah tersebut dapat ditarik kesimpulan bahwa adanya perilaku manusia merupakan peranan yang penting dari tindakan tidak aman merupakan unsur yang dapat menyebabkan kecelakaan. Pada bulan April 2016, dari BPJS Ketenagakerjaan mendata sebanyak 33.151 kasus yang menggunakan jaminan kecelakaan kerja, dengan jumlah 263,15 milyar dihabiskan untuk Kasus ini. Hal itu menunjukan masih tingginya angka kecelakaan kerja yang terjadi di Indonesia. Data didapatkan Pada tahun 2015, pihak Disnakertrans Jawa Tengah melaporkan data kecelakaan kerja di Kabupaten $X$ menduduki peringkat 5 untuk jumlah kecelakaan terbanyak, dengan jumlah 243 kasus. Kecelakaan yang disebabkan oleh mesin adalah masalah yang paling banyak di jumpai yaitu 171 kasus. Pada substandard action, Tidak menggunakan alat pelindung diri sejumlah $(25,53 \%)$ yang paling sering dilakukan terjadi pada penelitian yang dilakukan oleh PT.X menjelaskan bahwa, mengangkat beban dengan posisi janggal $(12,77 \%)$, dan berseda gurau berlebihan saat bekerja(12,77\%).

Pada PT.PJB UBJ O\&M PLTU Paiton Di Kabupaten Probolinggo pada bulan Januari hingga April 2016 terdapat 65 temuan substandard action, yaitu dimana temuan terbesar banyak dilakukan oleh bagian Pemeliharaan Mesin. Kenyataan yang terjadi dalam Penggunaan Alat Pelindung Diri (APD) 
Jurnal Kesehatan Masyarakat \& Gizi, e-ISSN: 2655-0849

Vol. 3 No. 2 Edisi November 2020 - April 2021

https://ejournal.medistra.ac.id/index.php/JKG

Received: 22 April 2021 :: Accepted: 30 April 2021 :: Published: 30 April 2021

terdapat penyebab tenaga kerja tidak menggunakan Alat Pelindung Diri (APD) karena ketidakpatuhannya. Meskipun ada perusahaan yang telah menyediakan APD dan menerapkan peraturan yang mewajibkan bagi setiap tenaga kerja untuk menggunakan APD. Perusahaan tersebut juga harus dapat menciptakan kepatuhan tenaga kerja dalam menggunakan APD. Cara yang dapat dilakukan untuk menumbuhkan kesadaran tenaga kerja supaya patuh menggunakan APD yaitu dengan membentuk budaya keselamatan dengan cara menggunakan APD (Kartika 2015). Pemulung dengan masa kerja dan tinggal di TPA Jatibarang $\geq$ 3tahun dapat mengalami gangguan pernapasan sebesar $(88,2 \%)$ (sianipar,2015).

Pada penelitian yang sudah dilakukan menyebutkan bahwa faktor yang berhubungan dengan perilaku aman, diantaranya seperti penelitian yang dilakukan oleh Hendrabuwana (2016), pada tahun 2016, pekerja di Departemen Cor PT Pindad Persero Bandung dengan penelitian deskriptif yang menggunakan metode cross sectional diperoleh $45,1 \%$ (23 orang) mempunyai berperilaku kerja selamat dan $54,9 \%$ (28 orang) dengan berperilaku tidak selamat. Sedangkan pada variabel yang berhubungan dengan perilaku bekerja dengan selamat adalah berbentuk pengawasan, peraturan, dan lingkungan. Selanjutnya, pada penelitian yang dilakukan oleh Sialagan (2017) para pekerja PT EGS Indonesia yang dilakukan pada bulan November tahun 2017, dengan banyaknya pekerja sejumlah 31 orang yang terdiri10 orang personil kantor dan 21 orang personil lapangan dengan menggunakan penelitian deskriptif dan dengan menggunakan pendekatan cross sectional, yaitu diperoleh $94 \%$ responden termasuk dalam kategori baik dengan berperilaku aman. Selain itu, didapatkan hubungan yang bermakna antara adanya faktor pengetahuan, faktor motivasi, faktor persepsi, peran rekan kerja, dan penyedia terhadap perilaku aman. Penelitian lainnya yaitu penelitian yang dilakukan oleh Helliyanti (2016), pada pekerja Dept. Utility and Operation PT Indofood Sukses Makmur Tbk Divisi Bogasari Flour Mills tahun 2016 dapat diperoleh responden yang berperilaku aman sebanyak $60 \%$ sedangkan yang tidak berperilaku aman sebanyak $40 \%$.

\section{METODE PENELITIAN}

Jenis penelitian yang diambil pada penelitian ini adalah dengan menggunakan desain eksperimental. Rancangan penelitian adalah quasy eksperimen dengan pendekatan timeseries design. Desain penelitian adalah pra eksperimen (One group pre and post test design) yaitu penelitian yang menggunakan satu kelompok subyek, pengukuran di lakukan sebelum dan setelah perlakuan, yaitu Pengaruh Promosi K3 Terhadap Penggunaan Alat Pelindung Diri Dan Perilaku Tidak Aman di PT.Cinta Raja Tahun 2020.

Sampel pada penelitian ini dengan menggunakan metode non probability sampling yaitu merupakan metode pengambilan sampel dengan hanya individu atau objek tertentu saja pada suatu populasi yang dipilih menjadi sampel. Teknik pengambilan sampel yang digunakan dalam penelitian ini adalah total sampling yaitu merupakan teknik pengambilan sampel dimana jumlah sampel sama dengan populasi. Alasan dari peneliti dengan mengambil total sampling karena dengan jumlah populasi yang kurang dari 100 seluruh 
Jurnal Kesehatan Masyarakat \& Gizi, e-ISSN: 2655-0849

Vol. 3 No. 2 Edisi November 2020 - April 2021

https://ejournal.medistra.ac.id/index.php/JKG

Received: 22 April 2021 :: Accepted: 30 April 2021 :: Published: 30 April 2021

populasi dijadikan sampel penelitian.Pengumpulan data nya yang dilakukan dalam penelitian ini adalah.

Data primer adalah data yang didapatkan dari sumber pertama, baik dari didapatkan dari individu atau perseorangan seperti dapat hasil wawancara atau hasil pengisian dari kuesioner yang biasa dilakukan peneliti. Teknik pengumpulan data yang dilakukan oelh peneliti dalam penelitian ini menggunakan tehnik observasi. Data sekunder sering dikatakan juga bahwa metode penggunaan bahan dokumen, karena penelitidalam hal ini tidak secara langsung mengambil data sendiri tetapi meneliti dan memanfaatkan data atau dokumen yang dihasilkan oleh pihakpihak lain.

\section{HASIL}

Tabel 1. Distribusi responden berdasarkan karakteristik usia, status kerja, lama kerja dan pendidikan di PT. Cinta Raja

\begin{tabular}{ccc}
\hline $\begin{array}{c}\text { Karakteristik } \\
\text { Responden }\end{array}$ & $\mathbf{n}$ & \% \\
\hline Usia & & 22,3 \\
a. $\begin{array}{l}20-30 \\
\text { tahun }\end{array}$ & 10 & 55,8 \\
b. $\begin{array}{l}31-40 \\
\text { tahun }\end{array}$ & 24 & 20,9 \\
c. $\begin{array}{c}41-50 \\
\text { tahun }\end{array}$ & 9 &
\end{tabular}

Status Kerja

$\begin{array}{lcc}\text { a. Karyawan } & 33 & 76,7 \\ \text { tetap } & & \\ \text { b. Karyawan } & 10 & 23,3 \\ \text { tdk tetap } & & \\ \text { Lama Kerja } & & \\ \text { a. < } 5 \text { tahun } & 24 & 55,8 \\ \text { b. > 5 tahun } & 19 & 44,2 \\ \text { Pendidikan } & & \\ \text { a. SMP } & 1 & 2,3 \\ \text { b. SMA } & 21 & 48,8 \\ \text { c. D3 } & 8 & 18,6 \\ \text { d. S1 } & 13 & 30,2\end{array}$

Tabel 1 menunjukkan bahwa berdasarkan usia, paling banyak pekerja di PT. Cinta Raja termasuk dalam kelompok 31-40 Tahun, yaitu sebanyak 24 orang $(55,8 \%)$. Jika dilihat berdasarkan status kerja, paling banyak pekerja adalah karyawan tetap, yaitu sebanyak 33 orang (76,7\%), Berdasarkan lama kerja, paling banyak merupakan pekerja dengan lama kerja < 5 Tahun, yaitu sebanyak 24 orang $(55,8 \%)$, dan berdasarkan pendidikan, paling banyak pekerja berpendidikan SMA yaitu sebanyak 21 orang $(48,8 \%)$.

Tabel 2. Rerata Penggunaan Alat Pelindung diri sebelum promosi K3 di PT. Cinta Raja

\begin{tabular}{lllll}
\hline $\begin{array}{l}\text { Penggunaan } \\
\text { APD }\end{array}$ & mean & $\mathbf{n}$ & SD & SE \\
\hline $\begin{array}{l}\text { Sebelum } \\
\text { Promosi K3 }\end{array}$ & 6,60 & 43 & 2,855 & 0,435 \\
\hline
\end{tabular}

Berdasarkan tabel 2 di atas diketahui bahwa rerata penggunaan alat pelindung diri sebelum dilakukan promosi $\mathrm{K} 3$ adalah 6,60 dengan standard deviasi 2,855. 
Jurnal Kesehatan Masyarakat \& Gizi, e-ISSN: 2655-0849

Vol. 3 No. 2 Edisi November 2020 - April 2021

https://ejournal.medistra.ac.id/index.php/JKG

Received: 22 April 2021 :: Accepted: 30 April 2021 :: Published: 30 April 2021

Tabel 3. Rerata penggunaan alat pelindung diri sesuadah promosi K3 di PT. Cinta Raja

\begin{tabular}{lcccc}
\hline $\begin{array}{c}\text { Penggunaan } \\
\text { APD }\end{array}$ & mean & n & SD & SE \\
\hline $\begin{array}{l}\text { Sesudah } \\
\text { Promosi K3 }\end{array}$ & 10,74 & 43 & 2,083 & 0,318 \\
\hline
\end{tabular}

Berdasarkan tabel 3 di atas diketahui bahwa rerata penggunaan alat pelindung diri sesudah dilakukan promosi K3 adalah 10,74 dengan standard deviasi 2,083 .

Hasil uji normalitas data dengan menggunakan uji shapiro-wilk menunjukkan bahwa nilai signifikansi penggunaan alat pelindung diri sebelum promosi K3 adalah 0,105 dan nilai signifikansi penggunaan alat pelindung diri sesudah promosi K3 adalah 0,077 (Lampiran uji normalitas data). Sehingga dapat disimpulkan bahwa semua data pada penelitian ini berdistribusi normal dan dapat dilanjutkan ke uji paired simple $t$ - test untuk mengetahu pengaruh promosi $\mathrm{K} 3$ terhadap penggunaan alat pelindung diri
Tabel 4.Pengaruh Promosi K3 terhadap Panggunaan alat pelindung diri

\begin{tabular}{lcccc}
\hline \multicolumn{4}{c}{ Paired Differences } \\
\hline & Mean & SD & $\begin{array}{c}\text { Mean } \\
\text { SE }\end{array}$ & $\begin{array}{c}\text { 95\% } \\
\text { Inter Di } \\
\text { Lowe }\end{array}$ \\
\hline $\begin{array}{l}\text { Penggunaan } \\
\text { APD }\end{array}$ & & & & \\
$\begin{array}{l}\text { Sebelum } \\
\text { dan sesudah }\end{array}$ & -4.140 & 2.284 & .348 & -4.84 \\
$\begin{array}{l}\text { Dilakukan } \\
\text { Promosi K3 }\end{array}$ & & & & \\
\hline
\end{tabular}

Tabel 4. menunjukkan bahwa rerata perbedaan penggunaan alat pelindung diri sebelum dan sesudah promosi K3 adalah 4,140 dengan standar deviasi 2,284. Berdasarkan hasil uji statistik dengan menggunakan uji paired sample t-test dengan tingkat kepercayaan $95 \%(a=0,05)$ diperoleh $p$ value $=0,000 \leq 0,05$, artinya ada pengaruh promosi $\mathrm{K} 3$ terhadap penggunaan alat pelindung diri di PT. Cinta Raja Tahun 2020.

Tabel 5. Rerata prilaku tidak aman sebelum Promosi K3 di PT. Cinta Raja

\begin{tabular}{lllll}
\hline & mean & n & SD & SE \\
\hline $\begin{array}{l}\text { Perilaku } \\
\text { tidak aman } \\
\text { sebelum } \\
\text { promosi k3 }\end{array}$ & 14,02 & 43 & 4,132 & 0,6 \\
\hline
\end{tabular}

Berdasarkan tabel 5 di atas diketahui bahwa rerata perilaku tidak aman sebelum dilakukan promosi K3 adalah 14,02 dengan standard deviasi4,132. 
Jurnal Kesehatan Masyarakat \& Gizi, e-ISSN: 2655-0849

Vol. 3 No. 2 Edisi November 2020 - April 2021

https://ejournal.medistra.ac.id/index.php/JKG

Received: 22 April 2021 :: Accepted: 30 April 2021 :: Published: 30 April 2021

Tabel 6. Rerata Prilaku Tidak aman sesudah promosi K3 di PT. Cinta raja

\begin{tabular}{|c|c|c|c|c|}
\hline & mean & $\mathrm{n}$ & SD & SE \\
\hline $\begin{array}{l}\text { Perilaku tidak } \\
\text { aman } \\
\text { sesudah } \\
\text { promosi K3 }\end{array}$ & 21,74 & 43 & 2,691 & 0,410 \\
\hline
\end{tabular}

Berdasarkan tabel 6 di atas diketahui bahwa rerata perilaku tidak aman sesudah dilakukan promosi $\mathrm{K} 3$ adalah 21,74 dengan standard deviasi 2,691. Hasil uji normalitas data dengan menggunakan uji shapiro-wilk menunjukkan bahwa nilai signifikansi perilaku tidak aman sebelum promosi $\mathrm{K} 3$ adalah 0,165 dan nilai signifikansi perilaku tidak aman sesudah promosi $\mathrm{K} 3$ adalah 0,175 (Lampiran uji normalitas data). Sehingga dapat disimpulkan bahwa semua data pada penelitian ini berdistribusi normal dan dapat dilanjutkan ke uji paired simple t-test untuk mengetahui pengaruh promosi $\mathrm{K} 3$ terhadap perilaku tidak aman.

Tabel 7. Pengaruh Promosi K3 Terhadap perilaku Tidak aman

\begin{tabular}{|c|c|c|c|c|}
\hline \multicolumn{5}{|c|}{ Paired Differences } \\
\hline & Mean & SD & $\begin{array}{c}\text { Mean } \\
\text { SE }\end{array}$ & $\begin{array}{c}95 \% \\
\text { Inter } \\
\text { Di } \\
\text { Lowe }\end{array}$ \\
\hline $\begin{array}{l}\text { Perilaku Tidak } \\
\text { aman } \\
\text { sebelum } \\
\text { dilakukan K3 }\end{array}$ & -7.721 & 3.390 & .517 & -8.76 \\
\hline
\end{tabular}

Tabel 7 menunjukkan bahwa rerata perbedaan perilaku tidak aman sebelum dan sesudah promosi K3 adalah 7,721 dengan standar deviasi 3,390.
Berdasarkan hasil uji statistik dengan menggunakan uji paired sample t-test dengan tingkat kepercayaan 95\% ( $a=$ 0,05 ) diperoleh $p$ value $=0,000 \leq 0,05$, artinya ada pengaruh promosi $\mathrm{K} 3$ terhadap perilaku tidak aman di PT. Cinta Raja Tahun 2020.

\section{Pembahasan}

Berdasarkan tabel 2 di atas diketahui bahwa rerata hasil dari penggunaan alat pelindung diri sebelum dilakukan promosi K3 adalah 6,60 dengan standard deviasi 2,855. Suatu Alat Pelindung Diri (APD) merupakan suatu kewajiban dimana pekerja yang sudah bekerja disebuah proyek pembangunan sebuah gedung, diwajibkan menggunakannya.

Berdasarkan tabel 3 di atas diketahui bahwa rerata penggunaan alat pelindung diri sesudah dilakukan promosi K3 adalah 10,74 dengan standard deviasi 2,083. Occupational Safety and Health Administration (OSHA) menyatakan bahwa pada Alat Pelindung Diri yang diciptakan untuk melindungi pekerja dari terjadinya cidera dan penyakit akibat kerja yang berasal dari kontak dengan bahan kimia, radiologi, fisik, elektrik, mekanis, atau bahaya tempat kerja lainnya. Tabel 4 menunjukkan bahwa rerata perbedaan penggunaan alat pelindung dirisebelum dan sesudah promosi K3 adalah 4,140 dengan standar deviasi 2,284. Berdasarkan hasil uji statistik yang didapatkan dengan menggunakan uji paired sample t-test dengan tingkat kepercayaan $95 \%$ ( $a=$ $0,05)$ diperoleh $\mathrm{p}$ value $=0,000 \leq 0,05$, artinya ada pengaruh promosi K3 terhadap adanya penggunaan alat pelindung diri pada PT. Cinta Raja Tahun 2020. Alat pelindung diri (APD)yang
Commented [I1]: Masukkan nilai signifikan. Tabel melewati kolom 
Jurnal Kesehatan Masyarakat \& Gizi, e-ISSN: 2655-0849

Vol. 3 No.2 Edisi November 2020 - April 2021

https://ejournal.medistra.ac.id/index.php/JKG

Received: 22 April 2021 :: Accepted: 30 April 2021 :: Published: 30 April 2021

Wajib dipakai ketika bekerja Terutama di tempat-tempat yang beresiko terjadinya kecelakaan kerja,

Berdasarkan tabel 5 di atas diketahui bahwa rerata perilaku tidak aman sebelum dilakukan promosi $\mathrm{K} 3$ adalah 14,02 dengan standard deviasi 4,132 .

Berdasarkan tabel 6 di atas diketahui bahwa rerata perilaku tidak aman sesudah dilakukan promosi K3 adalah 21,74 dengan standard deviasi 2,691. Adanya perbuatan yang positif yang dilakukan oleh seseorang akan di pandang positif bila orang lain mengerjakannya, dan dia akan percaya bahwa orang lain melakukannya. Keyakinan- keyakinan tersebut dapat berpengaruh pada sikap serta perilaku seseorang untuk melakukan suatu perbuatan yang di nilai baik atau tidak.

Tabel 4.7 menunjukkan bahwa rerata perbedaan perilaku tidak aman sebelum dan sesudah promosi K3 adalah 7,721 dengan standar deviasi 3,390. Berdasarkan hasil uji statistik yang sudah dilakukan dengan menggunakan $u j l$ paired sample t-test dengan tingkat kepercayaan $95 \%(a=0,05)$ diperoleh $p$ value $=0,000 \leq 0,05$, artinya ada pengaruh promosi $\mathrm{K} 3$ terhadap perilaku tidak aman di PT. Cinta Raja Tahun 2020. Hasil penelitian ini sudah disesuaikan dengan penelitian yang sudah ddilakukan oleh Karyani kepada 113 pekerja di Schlumberger.dari Indonesia tahun 2014 diperoleh bahwa promosi k3 adalah faktor yang paling berpengaruh pada perilaku aman. Pada penelitian inisebanyak 51 orang $(45,13 \%)$ yang berperilaku aman dengan kriteria kurang baik karena promosi $\mathrm{k} 3$ yang kurang baik, 10 orang $(8,85 \%)$ dengan berperilaku tidak aman karena promosi k3 yang baik. Selain itu, para pekerja yang pahammengenai promosi k3 yang dapat berperan baik dalam memiliki peluang untuk berperilaku aman 9,633 kali.

\section{KESIMPULAN}

Berdasarkan hasil penelitian dapat disimpulkan bahwa :

1. Berdasarkan hasil penelitian in dapat diketahui adanya karakteristik berdasarkanusia, paling banyak pekerja di PT. Cinta Raja termasuk dalam kelompok 31-40 Tahun, yaitu sebanyak 24 orang $(55,8 \%)$. Jika dilihat berdasarkan status kerja, paling banyak pekerja adalah karyawan tetap, yaitu sebanyak 33 orang $(76,7 \%)$, Berdasarkan lama kerja, paling banyak merupakan pekerja dengan lama kerja < 5 Tahun, yaitu sebanyak 24 orang $(55,8 \%)$, dan berdasarkan pendidikan, dan paling banyak pekerja berpendidikan SMA yaitu sebanyak 21 orang $(48,8 \%)$.

2. Berdasarkan hasil penelitian dapat diketahui bahwa dari jumlah 43 orangresponden, rerata yang menggunakan alat pelindung diri sebelum dilakukan promosi K3 adalah 6,60 dengan standard deviasi 2,855. Sedangkan darijumlah 43 orang responden, rerata penggunaan alat pelindung diri sesudah dilakukan promosi $\mathrm{K} 3$ adalah 10,74 dengan standard deviasi 2,083 .

3. Berdasarkan hasil penelitian yang didapat diketahui bahwa dari 43 orangresponden, rerata perilaku tidak aman sebelum dilakukan promosi K3 adalah sebanyak 
Jurnal Kesehatan Masyarakat \& Gizi, e-ISSN: 2655-0849

Vol. 3 No. 2 Edisi November 2020 - April 2021

https://ejournal.medistra.ac.id/index.php/JKG

Received: 22 April 2021 :: Accepted: 30 April 2021 :: Published: 30 April 2021

14,02 dengan standard deviasi 4,132. Sedangkan dari 43 orang responden, rerata perilaku tidak aman sesudah dilakukan promosi $\mathrm{K} 3$ adalah 21,74 dengan standard deviasi 2,691.

4. Rerata adanya perbedaan penggunaan alat pelindung diri sebelum dan sesudahpromosi $\mathrm{K} 3$ adalah 4,140 dengan standar deviasi 2,284. Berdasarkan hasil dari uji statistik dengan menggunakan uji paired sample t-test dengan tingkat kepercayaan 95\% (a $=0,05)$ diperoleh $p$ value $=0,000 \leq 0,05$, artinya ada pengaruh promosi $\mathrm{K} 3$ terhadap penggunaan alat pelindung diri di PT. Cinta Raja Tahun 2020

5. Rerata adanya perbedaan perilaku tidak aman sebelum dan sesudah promosi $\mathrm{K} 3$

6. adalah 7,721 dengan standar deviasi 3,390. Berdasarkan hasil uji statistik dengan menggunakan uji paired sample t-test dengan tingkat kepercayaan 95\% (a = $0,05)$ diperoleh $\mathrm{p}$ value $=0,000 \leq$ 0,05, artinya ada pengaruh promosi K3 terhadap perilaku tidak aman di PT. Cinta Raja Tahun 2020.
Helliyanti, (2017). Keselamatan Kerja \& Pencegahan Kecelakaan. Jakarta : PT Saksama.

ILO. (2013). Health and Safety in Work Place for Productivity. Geneva : International Labour Office. 2013.

Jamsostek, Kinerja, (2014). Jamsostek Bayar Klaim Rp12,89 T. Jakarta.

Kartika, (2015). Keselamatan Kerja \& Pencegahan Kecelakaan. Jakarta : PT Saksama.

Sialagan, (2017). Hubungan karakteristik pekerja dengan unsafe action pada tenaga kerja bongkar muat di PT.Terminal Petikemas Surabaya. Jurnal. HSE PT.Petikemas Surabaya.

Sianipar, R. H. (2009). Analisis risiko paparan Hidrogen Sulfida pada masyarakat sekitar TPA sampah Terjun Kecamatan Medan Marelan Tahun 20015 (Tesis, Universitas Sumatera Utara).

\section{DAFTAR PUSTAKA}

Hendrabuwana, (2016). Hubungan karakteristik pekerja dengan unsafe action pada tenaga kerja bongkar muat di PT.Terminal Petikemas Surabaya. Jurnal. HSE PT. Petikemas Surabaya. 